\title{
Promoting photonics learning and research among secondary school students
}

\section{Yoong Lam, Tuan-Kay Lim}

Yoong Koy Lam, Tuan-Kay Lim, "Promoting photonics learning and research among secondary school students," Proc. SPIE 4588, Seventh International Conference on Education and Training in Optics and Photonics, (28 May 2002); doi: $10.1117 / 12.468690$

SPIE Event: Education and Training in Optics and Photonics 2001, 2001, Singapore, Singapore 


\title{
Promoting Photonics Learning and Research among Secondary School Students
}

\author{
Yoong Koy Lam ${ }^{1}$, Tuan-Kay Lim ${ }^{2}$ \\ ${ }^{1}$ The Chinese High School, No. 673 Bukit Timah Road, Singapore 269735 \\ Phone: (65) 466-5912, Fax: (65) 468-1063 \\ Email: 1amyk@chs.edu.sg \\ ${ }^{2}$ Nanyang Technological University, \\ School of Electrical \& Electronic Engineering \\ Nanyang Avenue, Singapore 639798 \\ Phone: (65) 790-5018, Fax: (65) 792-0415 \\ Email: etklim@ntu.edu.sg
}

\begin{abstract}
As a premier institute of learning in Singapore, The Chinese High School (CHS) is committed to nurturing the high academic achievers in the country to be forerunners and leaders in research, technology, business and government. We have chosen to stimulate our talented young minds by constantly exposing them to new frontiers of knowledge and technology as one would find in photonics. Our strategies of achieving the objectives are the following:
\end{abstract}

1. Prepare a series of activity-based lessons that cater for all levels, particularly the juniors, so as to get students interested in the subject.

2. Organize talks and seminars by renowned scientists and entrepreneurs to motivate and to expose our pupils to new applications and developments in photonics.

3. Provide the students with top-notch facilities within the campus to encourage and to support more students to do research.

4. Establish strategic alliances with local and international organizations through mentorship, attachment and immersion programs.

5. Encourage teachers to upgrade themselves to keep abreast with the latest developments in photonics through participation in workshops and conferences.

6. Attract talented primary school students with special interest in photonics to join our school.

The CHS Photonics Learning and Research Center was set up in 2000. We are very fortunate to continue to obtain full support from the school administration, various professional bodies and institutes of higher learning, be it locally or from abroad, in running our programs.

\section{THE CHINESE HIGH SCHOOL - AN OVERVIEW}

The CHS has a total enrolment of about 2000 pupils, about one-fifth of these are scholars from this region. As an independent school, we could exercise greater autonomy in the appropriation of funds for school development or indulging in academic pursuits other than the core curricula set by the Singapore Ministry of Education.

As a school of excellent academic standing, it is natural that we have included as our mission to nurture high academic achievers to be forerunners and future leaders in research, technology, business and government. To achieve this target, the school has set aside a few millions dollars to set up ten Learning and Research Centers 
(LRC) such as in Information Technology, Biological Studies, Business and Finance, etc. Photonics LRC is another one of these.

\section{RATIONALE OF SETTING UP THE CHS PHOTONICS LRC}

The Singapore Economic Development Board (EDB) has categorically identified photonics as one area of rapid growth for Singapore in the coming decade. It has declared that Singapore "aims to be a global player in this arena and seeks to attract activities such as manufacturing of key components, development of optical devices and production processes as well as test bedding of network systems" (Singapore Investment News Photonics Supplement 2001, EDB March 2001)

Photonics is an integral part of biotechnology, information technology, nanotechnology, defense technology and others. It also forms the core of the nascent research in quantum computing, cryptography, holographic memory, etc. A student well trained in photonics is all too ready to venture in any one of the above fields. Given the immense opportunities generated by global advances in the photonics technology, it is no wonder that the Singapore government is strongly committed to growing the photonics industry. Thus we have set up the Singapore Center of Photonics Excellence (SCOPE) consisting of nine organizations as listed in Appendix A.

\section{OBJECTIVES OF THE CHS PHOTONICS LRC}

1. To expose our students to new developments in the areas of research and applications in photonics;

2. To engage our students to take up research projects in photonics;

3. To make learning of Science and Physics in school more relevant to students; and

4. To prepare students to meet the development needs of Singapore.

\section{OUR CONSTRAINTS}

\subsection{Time constraint}

All Singapore secondary school students sit for the Cambridge O-Level Examination at the end of their fouryear education. The O-Level Certificate is a prerequisite for the A-Level (junior college) study. Passes in ALevel subjects constitute the major part of the entrance requirements for a place at a local university.

On average, our students sit for 8 subjects (up to 18 papers) at one sitting for their O-Level Examination, with some taking as many as 9 or even 10 subjects. The curriculum is intensive by any standard as they use only two years, namely the Secondary Three and Secondary Four, for their preparation. In addition, the students are also heavily loaded with co-curricular activities, e.g., uniformed groups, sports or cultural activities. It is very difficult to slot in a formal photonics curriculum into their normal education.

\subsection{Financial constraint}

Photonics components and equipment are expensive. In our school the Photonics LRC has to compete with other enrichment activities as well as the core subjects for funds. Here we are lucky to have a very supportive Administration and Board of Governors in setting aside sufficient fund for our programs. However, with the global economic recession, we expect big challenges in Year 2002.

\subsection{Staff and deployment constraints}

Teachers who help to run the Photonics LRC programs are full-time Physics teachers. They are loaded with teaching their normal curriculum and also carrying out duties as expected of a teacher in charge of a particular co-curricular activity. In addition, school teachers are constantly acting as mentors or counselors to the students directly under their charge.

The area of photonics certainly requires very specific knowledge and skills to run courses and workshops. Thus, not all teachers will be comfortable with getting involved unless further training is provided. 


\section{OUR STRATEGIES}

We have adopted the following strategies to achieve our objectives:

5.1 Prepare a series of activity-based, fun-learning lessons that cater for all levels, particularly the juniors, $\underline{\text { so as to get students interested in the subject at a young age. }}$

The students learn basic properties of light in their Secondary Two Science curriculum. They go through a more structured treatment of optics in reflection, refraction, and wave characteristics in their Secondary Three Physics curriculum.

5.1.1 Our <Photonics Adventure Module> is an enrichment module for Secondary One students to sign up. This is a 3-hour module on basic types of light sources, applications of reflection and refraction, and simple projects of making a kaleidoscope and displaying laser Lissajous patterns using two mirrors attached to two small electric motors.

This introductory hands-on module was conducted 3 times to allow as many Secondary One pupils to participate as possible. 90 Secondary One students (or slightly less than $25 \%$ of the Secondary One cohort) signed up for this module this year.

5.1.2 Our <Fun with Photonics Module> is aimed at students from Secondary Two onward. In this module they learn the diffraction and interference of light. They also have some experience with optoelectronics. The students are allowed to investigate the property of some light-sensitive electronics components by

i) building a simple optical communication circuit, and

ii) determining the frequency of transmission of a digital signal.

The two modules were well received. We also invited students from neighboring schools to join the second module.

5.1.3 Our teachers also conducted holography courses for interested students. Students learned the art of making both reflection and transmission holograms.

With more students participating in these activities, we would expect some of them venturing into some research of their own interest.

5.2 Organize talks and seminars by renowned scientists and entrepreneurs to motivate and expose our teachers and pupils to new applications and developments in photonics.

Among our distinguished speakers was Dr. Robert Breault of BRO Inc., USA. Dr. Breault shared his experience with our students on his path to the photonics world and his work on the Hubble telescope. Dr Allan Lee, a NASA scientist talked to our students about his involvement with the Cassini mission to Jupiter. There was also Dr. Ping Koy Lam of Australian National University (ANU), Canberra, sharing his research in quantum squeezed states and quantum teleportation.

In addition, we also organized talks for teachers to keep them updated with the latest in photonics technology. We were honored to have Mr. Chen Jun Wei of Nanyang Technological University (NTU) sharing with us his research in Biophotonics.

Such talks greatly broadened the outlook of the students and teachers and motivated them to go into research in photonics or Physics.

5.3 Provide our students with top-notch facilities within the campus to encourage and support interested students to do research. 
The CHS Photonics LRC was officially launched in 2000. Our starting fund for a photonics lab was more than SGD 100K. The budget for Year 2001 was 30K. (See Appendix B: Budget)

5.4 Establish strategic alliances with local and international organizations through mentorship, attachment and immersion programs.

In 2000, 23 of our students and 2 teachers made a trip to the Silicon Valley and the Optics Valley. We had an educational tour of the research laboratory of Advanced Light Sources in Berkeley and the Gravity Probe Center in Stanford. In the Optics Valley, we were very privileged and honored to be hosted by Dr. Robert Breault. We had a rare chance of a guided tour of some manufacturers of photonics devices, optical software houses and the Mirror Lab of University of Arizona.

Another group of 46 students and teachers attended a 6-day Photonics course in ANU, Canberra. The students learned the basics of optical communications, interferometry, and image processing.

In the local scene, we are very fortunate to have Associate Professor Anand Krishna Asundi and Associate Professor Lim Tuan Kay of NTU and Mr. Andrew Sabaratnam of Ngee Ann Polytechnic mentoring and guiding our boys in their project work. In addition, Dr. Gopal M. Hegde of Ngee Ann Polytechnic also conducted Photonics lessons for our students and teachers.

We also managed to get the support of organizations such as the PSB Corporation (formerly Singapore Productivity and Standards Board), notably Dr. Luh Cherng Wong and Dr. Ji Kai Fu for helping us to make connections to other professional bodies of optics and photonics. Micron Semiconductor Asia has helped us by accepting our students in their School Outreach Program.

5.5 Encourage teachers to upgrade themselves to keep abreast with the latest development in photonics through participation in workshops and conferences.

The school has set aside professional development funds for teachers to advance in specific areas of their interest. Sending teachers to courses and conferences or giving subsidies to teachers to pursue a higher degree are some of the initiatives taken to motivate teachers to take up research themselves or guiding the students in research work.

\subsection{Attract talented primary school students with special interest in photonics to join our school.}

Through our open house and special functions, we invited primary school kids to visit our Photonics LRC and to participate in activities organized for them. In this way, interested pupils will join us when they opt for a secondary school and we will have a pool of talented and interested pupils to start working with.

\section{Future Plan}

The immediate plan for the future is to attract more students to engage in project work and research related to photonics. This year, they are a total of 5 related projects submitted by our students in the annual CHS Projects Day Competition. This number is far from satisfactory.

The work plan for Year 2002 is shown in Appendix C: Workplan 2002.

There is a concrete plan of expanding the present Photonics LRC along with the others to be housed in one building. The number of photonics laboratory will be increased. The proposal is still waiting for approval.

\section{Our Appreciation}


We like to take this opportunity to express our sincere thanks and heart felt appreciation to the following professionals for accepting to be our Honorary Advisors. They have made great contributions to promoting photonics learning in The Chinese High School. Our Honorary Advisors are

1. Dr. Robert Breault of BRO Inc. USA,

2. Associate Professor Anand Krishna Assundi, NTU

3. Associate Professor Lim Tuan Kay, NTU

4. Mr. Andrew Sabaratnam of Ngee Ann Polytechnic

5. Dr. Ping Koy Lam, ANU

6. Mr. Jun Wei Chen, NTU

Apart from giving us all the encouragement we need, they readily come forward to give us support in the form of valuable advice and technical help. (See Appendix D: Contributions).

\section{CONCLUSION}

We have only taken a small step in educating our students and ourselves in photonics. We are still a long way from achieving the objectives set. But with the caliber of students we get and all the support we enjoy, we are confident of achieving our target.

\section{APPENDIX A: SCOPE}

The Singapore Center of Photonics Excellence (SCOPE) comprises the following organizations which are all linked to the SCOPE website at http://www.scope.org.sg:

EDB - The Economic Development Board of Singapore

(Website: http://www.edb.gov.sg or http://www.sedb.com/edbcorp/index.jsp)

PSB - The PSB Corporation (formerly Singapore Productivity and Standards Board)

(Website: http://www.psb.gov.sg)

NSTB - National Science and Technology Board

(Website: http://www.nstb.gov.sg)

DSI - Data Storage Institute

(Website: http://dsi.nus.edu.sg)

GINTIC - The Gintic Institute of Manufacturing Technology

(Website: http://www.gintic.gov.sg)

IME - Institute of Microelectronics

(Website: http://www.ime.org.sg)

IMRE - Institute of Materials Research Engineering

(Website: http://www.scope.org.sg/imre.htm )

NTU - The Nanyang Technological University

(Website: http://www.ntu.edu.sg)

NUS - The National University of Singapore

(Website: http://www.nus.edu.sg) 


\section{APPENDIX B: BUDGET}

Start up Budget 2000

(In Singapore Dollars)

1. Photonics Lab Preparation

(Partitions, installations, cabinets and furniture)

$\$ 20,000$

2. Optical Benches

(Breadboards and supporting tables)

$\$ 25,000$

3. Optical Components

(Lasers, mirrors, lenses, beam-splitters, etc.)

$\$ 50,000$

4. Operation Costs

(Instructors' fees, teaching aid, maintenance, etc.)

$\$ 10,000$

Total

$\$ 105,000$

Budget For 2001

1 Proposed amount required for the purchase of

$\$ 10,000$

Optics Components (Addition of apparatus to 8 sets,

Photodetectors, Polarisers, etc)

2 Proposed amount required for the purchase of

$\$ 5,000$

Teaching Aids (OHP, Optoelectronics Kits,

Optics Software, Charts \& Frames)

3 Proposed amount required for the purchase of

$\$ 10,000$

Holography Equipments (Laser and holder, Holographic Plates \&

Chemicals)

4. Proposed amount required for Lab Improvements

$\$ 5,000$

(Lighting, ventilation \& networking. Optical benches \& Tables)

Total $\$ 30,000$

\section{APPENDIX C: WORK PLAN 2002}

\begin{tabular}{|l|l|l|l|}
\hline \multicolumn{1}{|c|}{ Activity } & \multicolumn{1}{|c|}{ Description } & \multicolumn{1}{c|}{ Participants } & \multicolumn{1}{c|}{$\begin{array}{c}\text { Time frame/ } \\
\text { Duration }\end{array}$} \\
\hline 1. Photonics Adventure & $\begin{array}{l}\text { An introduction to properties of light. } \\
\text { Reflection and Refraction }\end{array}$ & Sec1 students & $\begin{array}{l}\text { March and } \\
\text { September term } \\
\text { breaks (3 h) }\end{array}$ \\
\hline 2. Basic Photonics & Diffraction and interference/ Lenses & Sec1 \& Sec2 & Once weekly \\
\hline
\end{tabular}




\begin{tabular}{|l|l|l|l|}
\hline \multicolumn{1}{|c|}{ Course } & $\begin{array}{l}\text { Fiber-optics and communication/ Light } \\
\text { sources and laser }\end{array}$ & students & $\begin{array}{l}\text { during term } \\
\text { time }(20 \mathrm{~h})\end{array}$ \\
\hline 3. Fun with Photonics & Optoelectronics \& Optical communication & $\begin{array}{l}\text { Sec3 \& Sec4 } \\
\text { students }\end{array}$ & $\begin{array}{l}\text { Term 1 Break } \\
(3 \mathrm{~h})\end{array}$ \\
\hline $\begin{array}{c}\text { 4. Experimental } \\
\text { Techniques in } \\
\text { Photonics }\end{array}$ & $\begin{array}{l}\text { Talk or workshop on emerging trends by } \\
\text { invited speaker }\end{array}$ & $\begin{array}{l}\text { Teachers \& } \\
\text { students }\end{array}$ & June Holidays \\
\hline $\begin{array}{c}\text { 5. Intermediate Photonics } \\
\text { Course }\end{array}$ & $\begin{array}{l}\text { Intensive 5-lesson module } \\
\text { Laser systems and measurements }\end{array}$ & $\begin{array}{l}\text { Sec2 \& Sec3 } \\
\text { students }\end{array}$ & $\begin{array}{l}\text { Sept. break } \\
(10 \mathrm{~h})\end{array}$ \\
\hline $\begin{array}{c}\text { 6. Special projects } \\
\text { Holography/ Laser show } \\
\text { Biophotonics projects }\end{array}$ & $\begin{array}{l}\text { Teachers \& } \\
\text { students }\end{array}$ & Ongoing \\
\hline 7. ANU attachment & $\begin{array}{l}\text { 10-day attachment course cum study tour } \\
\text { in Canberra, Australia }\end{array}$ & $\begin{array}{l}\text { Teachers \& } \\
\text { students }\end{array}$ & $\begin{array}{l}\text { June or Dec } \\
\text { Holidays }\end{array}$ \\
\hline
\end{tabular}

\section{APPENDIX D: CONTRIBUTIONS}

Dr. Breault of BRO Inc. USA was here to give a most inspiring and enlightening speech to a group of our graduate students and teachers during his brief stay in Singapore in 1999. He hosted our group of students visiting the Optics Valley the following year, taking the boys way up to Kitt Peak and acted as guide to the array of telescopes and to Mount Lemmon for a snow war!

Assoc. Prof. Asundi of NTU has advised us on the Photonics Lab set-up and lent us his photonics equipment and his collection of holograms during the Photonics Fair held in conjunction with the launch of the Photonics LRC, 2000. He has acted as mentor to a few of our students in doing their projects.

Assoc. Prof. T. K. Lim of NTU has been guiding us through photonics meetings, providing us with the networking we enjoyed with SPIE and also guided our boys in their projects.

Dr. P. K. Lam of ANU, Canberra gave a captivating and insightful talk to our pupils on quantum squeezed states and teleportation in 2000. Last year he also arranged for a group of 46 of our students to be attached to ANU Photonics Centre for a 6-day course and took them to race with the kangaroos in the Titbinbila Wildlife Park.

Mr. Andrew T. Sabaratnam had conducted courses for our students in our Centre. He has mentored our pupils in their project work. He has also kindly allowed our teachers and students to use the facilities in Ngee Ann Polytechnic Photonics Center for research and training.

Mr. J. W. Chen of NTU has helped us immensely for sharing with us the fine points of equipping and maintaining our Photonics LRC. 